\title{
Rekonstruksi Pemikiran Kartini tentang Keagamaan untuk Memperkuat Integrasi Nasional
}

\author{
Lilis Muchoiyyaroh \\ SMA Al Hikmah Surabaya
}

Alamat korespondensi: lilis.muchoiyyaroh@gmail.com

Diterima/ Received: 27 November 2018

Disetujui / Accepted: 4 Juli 2019

\section{Abstract}

Kartini's complex thinking about her nation was the result of observations and experiences that she experienced empirically. But Kartini's ideas about religion were explicitly influenced by the surrounding environment, both European and indigenous people themselves. This study focuses on the reconstruction of Kartini's thinking in the field of religion and the social background of the emergence of this thought. Therefore, this study uses historical methods with a social history approach to identify Kartini's ideas in the religious field. The reconstruction of her ideas as one of the national integration efforts that cannot be separated from the influence of the religiosity and social background of the people around her. Kartini's thinking about religion was critical, open, and pluralistic, which was concerned with the division of the nation due to religious differences.

Keywords: Kartini Ideas; Religious; National Integration.

\section{Abstrak}

Pemikiran Kartini yang kompleks tentang bangsanya merupakan hasil pengamatan dan pengalaman yang secara empirik dialaminya. Namun pemikiran Kartini tentang keagamaan secara khusus mendapat pengaruh dari lingkungan sekitar, baik orang Eropa maupun orang pribumi sendiri. Kajian ini memfokuskan pada rekonstruksi pemikiran Kartini pada bidang keagamaan dan latar belakang sosial munculnya pemikiran tersebut. Oleh karena itu, kajian ini menggunakan metode sejarah dengan pendekatan sejarah sosial untuk mengidentifikasi pemikiran Kartini dalam bidang keagamaan. Rekonstruksi pemikiran Kartini sebagai salah satu upaya integrasi nasional tidak dapat dilepaskan pada pengaruh dari latar belakang sosial keagamaan orang-orang di sekitar Kartini. Pemikiran Kartini mengenai keagamaan bersifat kritis, terbuka, dan pluralistik yang prihatin dengan perpecahan bangsa karena faktor perbedaan agama.

Kata Kunci: Pemikiran Kartini; Keagamaan; Integrasi Nasional.

\section{Pendahuluan}

Toleransi beragama pada masa tradisional menunjukkan bahwa Indonesia mampu bersatu meskipun memiliki latar belakang perbedaan agama. Namun integrasi itu semakin meredup ketika Indonesia dijajah oleh Pemerintah kolonial Belanda. Sejak tahun 1870 politik kolonial Tanam Paksa diganti sistem liberal yang membuka pintu selebar-lebarnya bagi kaum industri dan kaum modal swasta Belanda untuk 
menanam modal di Hindia Belanda dan mencari keuntungan sebesar-besarnya dengan bebas. Alasan kaum industri dan kaum modal swasta Belanda mendukung sistem liberal adalah agar dapat membangkitkan semangat bekerja di kalangan rakyat pribumi sehingga dengan sendirinya memberikan kemakmuran dan kesejahteraan.

Dalam kenyataannya, pelaksanaan sistem liberal tidak sesuai dengan alasan dan teori pendukung sistem liberal. Memang benar sistem liberal memberi kemakmuran dan kesejahteraan, tetapi untuk kaum industri dan kaum modal swasta Belanda, bukan untuk rakyat pribumi. Rakyat pribumi semakin menderita dan melarat, sehingga banyak petani beserta anak dan istri terpaksa menjadi buruh di perkebunanperkebunan dan pabrik-pabrik Belanda karena kehilangan hak atas tanah-tanah para petani.

Kemiskinan dan penderitaan rakyat pribumi mendapat respons dari orangorang Belanda yang simpati dan tergerak hatinya untuk memperbaiki nasib rakyat pribumi. Kritik terhadap sistem liberal dipelopori oleh Pieter Brooshooft, seorang wartawan Koran De Locomotief. Simpati dari orang-orang Belanda semakin mencuat sejak karangan Mr. Coenraad Th. van Deventer yang berjudul "Hutang Budi" dan "Suara Dari Jawa" menggetarkan hati masyarakat Belanda. Tuan Van Deventer mengecam kebijakan pemerintah Belanda yang hanya mementingkan uang tanpa memikirkan nasib rakyat pribumi layaknya mesin pencetak uang, bukan manusia. Kritik itu kemudian berujung pada penetapan Politik Etis atau politik hutang budi sebagai politik kolonial baru oleh Ratu Belanda pada 17 September 1901.

Hal nyata yang dilakukan Belanda dalam penerapan politik etis salah satunya adalah dengan membuka akses pendidikan Barat bagi rakyat pribumi. Pendidikan Barat bagi rakyat pribumi memiliki tujuan terselebung yang tidak begitu luhur. Dengan adanya pendidikan Barat, pemerintah Belanda berharap akan lahir tenagatenaga terampil dari rakyat pribumi dengan gaji yang murah. Di sisi lain, politik etis sebenarnya memiliki tujuan terselubung, yaitu untuk mengalihkan fokus masyarakat Jawa terhadap Islam dan paham Pan-Islamisme yang sedang berkembang pesat di Timur Tengah saat itu (Kahin, 2013).

Tujuan tidak baik di atas kemudian menjadi "bumerang" bagi pemerintah kolonial Belanda. Kelak banyak rakyat pribumi yang merupakan lulusan-lulusan sekolah Eropa menjadi terbuka dan mengusahakan adanya perbaikan hidup bahkan persatuan. Salah satunya adalah Kartini. Pada 8 Agustus 1900, Tuan J. H. Abendanon selaku Direktur Departemen Pendidikan dan Pengajaran Hindia Belanda dan istrinya datang ke kediaman Bupati Jepara, yaitu Ario Sosroningrat yang tidak lain adalah Ayah dari Raden Ajeng Kartini untuk mendapat masukan dari penguasa pribumi perihal program Politik Etis di bidang pendidikan (Muchoiyyaroh, 2014, p. 3).

Bupati Jepara yang meniupkan spirit pendidikan Eropa kepada putra-putrinya untuk kali pertama adalah Tjondronegoro. Salah seorang putra dari Tjondronegoro adalah Raden Mas Ario Sosroningrat (ayah dari Kartini). Dengan demikian, dapat dikatakan bahwa Kartini sebenarnya telah menerima buah hasil jerih payah kakeknya. (Ulum, 2015). Diketahui melalui surat-surat Kartini, latar belakang keluarga yang mendapat kemudahan dalam mengakses pendidikan Eropa, diperkuat dengan 
kebijakan Politik Etis untuk kaum bumiputera, menjadi pintu bagi Kartini untuk bertemu dengan orang-orang Belanda yang kemudian dijadikan momen untuk berkorespondensi. Kesempatan untuk saling bertukar pikiran tentang budaya, kondisi masyarakat, dan agama masing-masing menjadi semakin terbuka. Sistem feodalisme dan adat istiadat Islam kejawen sering kali menjadi bahan perbincangan Kartini dengan sahabat-sahabat pena Kartini yang memicu terjadinya perpecahan karena faktor agama.

Keprihatinan Kartini akan manusia yang saling membenci, saling menghina karena pemahaman agama yang dangkal menjadi realitas di negeri ini, negeri yang menjadi tumpah darah masyarakat plural. Berulang kali terdapat fenomena penistaan agama oleh satu orang dengan agama yang menyinggung orang lain dengan agama yang lain pula. Kekerasan oleh kelompok yang satu terhadap yang lain, pembenaran akan agama sendiri menjadi pemandangan sehari-hari sebagai penodaan dan penyimpangan terhadap kesucian ajaran agama itu sendiri saat ini.

Beberapa kajian yang ada belum pernah menyebutkan peran Kartini dalam bidang keagamaan secara khusus. Selama ini kajian yang ada bertumpu pada pandangan Kartini dalam pendidikan untuk perempuan. Pandangan itu dikaitkan dengan ajaran Islam yang menekankan pentingnya pendidikan aqidah atau moral sejak dini untuk seorang ibu (Aminah, 2005). Bagaimana bisa seorang perempuan mampu mengajari anak-anaknya kelak jika tidak diberi kesempatan mengenyam pendidikan lebih-lebih pendidikan dari agamanya sendiri (Islam). Hal ini senada yang dilakukan Sudrajat (2007) melihat sosok Kartini sebagai tokoh emansipasi perempuan yang pemikirannya dipengaruhi oleh orang-orang di sekitarnya.

Sementara itu, Abidin (2015) mencoba menguak tentang percakapan dan makna tersirat dalam surat-surat Kartini kepada Ny. Abendanon-Mandri tentang keagamaan di Hindia Belanda, seperti adanya praktik zending oleh pemerintah kolonial Belanda hingga niat terselebung Ny. Abendanon-Mandri yang berusaha meng-Kristen-kan Kartini. Hal ini senada dengan Nadhifah (2017) yang berupaya menunjukkan posisi pemikiran Kartini dalam mengritik metode pendidikan agama Islam yang dianggap doktriner semasa hidupnya. Menurutnya, Kartini mengusulkan perlu ada penerjemahan kitab-kitab agama dalam memudahkan proses mempelajari ilmu agama Islam. Nadhifah (2017) juga mengungkapkan bahwa Kartini berhasil menginspirasi beberapa kiai dan ulama dalam membangun pendidikan pesantren khusus perempuan. Berdasar karya-karya di atas, dapat ditunjukkan bahwa belum ada kajian yang secara spesifik mengulas mengenai pemikiran keagamaan dari Kartini yang dikaitkan untuk memperkuat integrasi bangsa.

\section{Metode}

Kajian ini menggunakan metode sejarah dengan pendekatan filosofis. Maksud dari pendekatan filosofis yaitu pembahasan secara kritis atas masalah yang menjadi topik bahasan diiringi dengan berfikir secara mendalam, sehingga hikmah, hakikat atau inti dari pokok persoalan dapat dimengerti dan dipahami secara logis yang diharapkan bisa memberi pemahaman yang lebih baik. Pendekatan filosofis mencoba melakukan 
refleksi ulang tentang pengalaman, keyakinan dan asumsi dasar dalam dimensi tertentu (Fisher, 1999).

Oleh karena itu, pendekatan filosofis dalam kajian ini menekankan pada dimensi kesadaran kritis dalam memahami pemikiran Kartini melalui surat-suratnya. Kesadaran kritis (critical consciousness) lebih melihat aspek sistem dan struktur sebagai sumber masalah (Freire, 2005). Pemikiran filosofis mengenai agama bukan merupakan cabang teologi melainkan sebagai cabang filsafat dan ada empat cabang dalam pendekatan filosofis, antara lain: logika, metafisika, epistemologi, dan etika. Pelaksanaan pendekatan filosofis dalam bahasan ini menekankan pada analisis etika, yakni sebuah studi tentang "perilaku" atau tentang nilai-nilai yang mengatur cara hidup (Hick, 1988).

\section{Agama yang Berkembang di Lingkungan Kartini}

Penerapan Politik Etis yang seharusnya dilaksanakan untuk meningkatkan taraf kehidupan masyarakat melalui edukasi, transmigrasi, dan irigasi ternyata memiliki tujuan lain. Melalui edukasi, kepentingan pencerahan atau kepentingan penyebaran agama Kristen disisipkan dalam pendidikan Barat yang diajarkan kepada kaum Bumiputera. Selain itu, humanitarianisme juga diajarkan kepada kaum bumiputera untuk melawan liberalisme, sehingga menjadi logis anak-anak pribumi yang berkesempatan sekolah di sekolah "bentukan Belanda" mengetahui tentang agama Kristen.

Penyebaran agama Kristen yang sering kali disebutkan oleh Kartini dengan istilah zending dan berulang kali mengatakan "yang penting manusia baik hati"; merupakan kata andalan orang-orang penganut humanitarianisme. Tentang zending, Kartini secara terang-terangan menolak zending di Jepara, Jawa Tengah dan Mojowarno, Jawa Timur yang dilakukan pemerintah kolonial Belanda saat itu (KITLV-LIPI, 2000, p. 64).

Masyarakat Jawa sebelum Hindu-Buddha datang telah memiliki sistem kepercayaan sendiri yang disebut dengan animisme dan dinamisme. Herusatoto (1991) berargumentasi bahwa suku bangsa Jawa purba mempunyai kepercayaan yang disebut animisme, suatu kepercayaan yang menganggap bahwa roh atau jiwa bersemayam pada semua benda, tumbuh-tumbuhan, hewan, dan pada manusia sendiri. Di samping animisme, mereka juga memegang kepercayaan dinamisme, yaitu kepercayaan akan adanya tenaga magis pada manusia, binatang, tumbuh-tumbuhan, dan benda-benda, juga dalam sebuah mantra atau tulisan-tulisan simbol pada bendabenda magis yang dipasang.

Berkembangnya Islam di Indonesia sama sekali berbeda dari perkembangan yang ada di Eropa. Para ulama yang dikirim ke Jawa khususnya harus berhadapan dengan orang-orang cerdas Majapahit dengan kultur Hindu-Buddha, jelas begitu sulit untuk menyebarkan agama Islam; sehingga beberapa cara damai ditempuh untuk perlahan orang-orang Majapahit dan Jawa bersedia memeluk agama Islam. Cara damai itulah pada akhirnya menimbulkan sebuah konsepsi baru dari perkembangan agama Islam di Jawa yang dikenal dengan Islam Kejawen. Islam Kejawen merupakan 
kebiasaan yang dilakukan oleh masyarakat Jawa yang beragama Islam dengan masih melestarikan tradisi Hindu-Buddha (Koentjaraningrat, 1984).

Sebagai elite dalam masyarakat Jawa, kaum priyayi mempunyai lebih banyak kesempatan untuk memperoleh pengetahuan, baik tradisional maupun modern, jika dibandingkan rakyat biasa. Seorang priyayi memang dididik untuk menjalankan tata krama perilaku tertentu yang meninggikan martabat mereka (Farela, 2017, p. 81). Mereka juga berkesempatan berkenalan dengan berbagai kepercayaan dan agama. Priyayi santri adalah sebutan untuk seseorang yang aktif melibatkan diri dalam agama Islam. Sementara itu, priyayi abangan adalah sebutan untuk seseorang yang tidak begitu hirau dengan syari'at Islam, dan sebagian masih kukuh memeluk agama leluhur mereka, yaitu Islam Kejawen.

Islam bagi golongan priyayi hanya digunakan untuk melengkapi narasi mistik. Mistik priyayi memang sulit dikompromikan dengan ajaran tasawuf murni. Dalam hal ini, mereka terkesan menyamakan kedudukan Tuhan dengan manusia, yang tersirat pada ungkapan manunggaling kawula-Gusti. Sementara itu dalam Islam, Tuhan jelas berbeda dari manusia. Akibatnya, penerapan ajaran Islam dalam kehidupan seharihari di kalangan priyayi abangan tidak cukup kuat. Sebaliknya, kepercayaan mistik dengan dibalut Islam lah, sehingga Tuhan diibaratkan dengan suatu kebaikan. Bagi mereka, kebaikan adalah sesuatu yang paling luhur dan penting untuk dilakukan oleh manusia.

Berangkat dari ciri-ciri masyarakat Jawa dalam tataran budaya, struktur sosial, dan agama menurut Geertz, maka keluarga Raden Ajeng Kartini dapat dikategorikan sebagai priyayi. Gelar "Raden Ajeng" yang tersemat namanya membuktikan bahwa Kartini berasal dari golongan priyayi (Soeroto, 1984, p. 126), meskipun Kartini sendiri dalam curahan hatinya lebih senang dengan posisinya sebagai manusia biasa tanpa embel-embel "Raden Ajeng" atau "Raden Ayu" (Toer, 2003).

\section{Pengaruh Orang-Orang di Sekitar Kartini}

Lingkungan memiliki pengaruh yang besar dalam proses pembentukan seseorang, terutama melalui interaksi secara intens, baik dengan keluarga maupun sahabat. Pemikiran Kartini tentang agama tidak dipungkiri sangat dipengaruhi oleh orangorang di sekitar, baik dari pihak keluarga maupun sahabat-sahabat korespondensi yang berasal dari Eropa. Pemikiran Kartini tentang agama dapat diketahui melalui surat-suratnya kepada sahabat-sahabatnya di Eropa. Berikut ini beberapa orang yang memiliki pengaruh atas pemikiran Kartini tentang keagamaan:

\section{Nellie van Kol}

Pikiran-pikiran religius Kartini banyak dipengaruhi oleh teman-teman pena berbangsa Belanda dan buku-buku bacaan Eropa. Salah seorang teman pena Kartini yang isi suratnya banyak mengulas tentang Tuhan dan agama adalah Nellie van Kol. Nellie van Kol adalah seorang Kristen yang taat dan suaminya (Ir. Henri van Kol) juga seorang penganut okultisme. Berikut adalah kutipan surat Kartini yang dikirimkan 
kepada Nellie van Kol pada 20 Agustus 1902 yang memperbincangkan pokok "kecemburuan Tuhan":

"God is najiverig, zegt men; Hij duldt niet, dat men andere goden aanbidt dan Hem en straft daarom den mensch met bittere ontgoocheling, die zich goden schept en hen aanbidt met goddelijke vereering" (Abendanon, 1976, p. 269).

“Tuhan itu cemburuan, kata orang. Dia tidak mengizinkan orang menyembah dewa-dewa lain kecuali Dia. Karena itulah Dia menyatakan hukuman dengan cara menyadarkan orang yang menciptakan dewa-dewa bagi diri mereka sendiri dan menyembahnya dengan penghormatan yang setinggi-tingginya. Kesadaran adalah hukuman yang pahit rasanya" (Sutrisno, 1985, p. 253).

Persoalan yang dihadapi Kartini yaitu apabila Tuhan bersifat cemburuan, apakah berarti bahwa Ia hanya menyetujui satu agama saja? Apakah Nellie van Kol hendak mengusulkan kepadanya bahwa hanya agama Kristen saja yang benar? Sudah barang tentu Kartini tidak akan bisa menyetujui hal itu. Sebab jikalau demikian, bagaimana dengan agama-agama lain, terutama agama yang dipeluknya? Apakah agama itu bukan agama yang benar? Dalam surat yang lain Kartini memberikan komentar sebagai berikut:

\begin{abstract}
"Tapi menurut kami, jangan ada ilah lain di hadapan-Ku", adalah sebuah perintah yang penuh kasih sayang. Bukankan perintah itu memuat peringatan yang sungguh-sungguh kepada manusia bahwa: manusia adalah manusiamakhluk yang bersifat khilaf ... Ah, sekiranya peringatan itu dipahami secara lebih baik; alangkah banyaknya penderitaan pahit yang bisa dihindari oleh umat manusia!"' (Sutrisno, 1985, pp. 253-254).
\end{abstract}

Tuhan "cemburu" karena manusia khilaf. Mereka memaknai Tuhan dan agama untuk kepentingan mereka sendiri. Egoisme manusia disembunyikan dalam kedok agama, dan mereka memakai nama Tuhan sekadar untuk menutupi perbuatan jahat mereka. Tuhan "cemburu” karena manusia hanya memakai-Nya untuk kepentingan duniawi mereka sendiri. Pada akhir kutipan tersebut, Kartini menghendaki agar ada pemahaman yang lebih baik tentang soal "kecemburuan dan peringatan Tuhan".

Jelas bahwa kekhilafan manusialah yang membuat "cemburu" dan kemudian Dia memberi peringatan agar manusia tetap berada pada jalan yang benar, yaitu jalan yang menuju kepada kasih sayang. "Pemahaman yang lebih baik", sebagaimana disinggung Kartini dalam kutipan surat di atas memang dengan sungguh-sungguh diupayakan. Gagasan Kartini tentang agama pada dasarnya memang terkait dengan minatnya untuk memikirkan hubungan antaragama yang merupakan persoalan utama dalam kehidupan kebatinannya. 


\section{R.M. Abendanon-Mandri}

Nama lengkap dari R.M. Abendanon-Mandri adalah Rosa Manuela Abendanon Mandri. R.M. Abendanon merupakan istri dari J.H. Abendanon; seorang Direktur Pengajaran Kementerian Pengajaran dan Kerajinan di Hindia Belanda sejak tahun 1900 yang juga sosok yang mengumpulkan surat-surat Kartini dan dibukukan pada 1911. Kedekatan R.M. Abendanon dengan Kartini begitu intim, sehingga sering kali Kartini memanggilnya dengan sebutan "Ibu kandungku yang sangat manis".

Dalam suratnya kepada Ny. Abendanon, Kartini pernah membahas kekecewaannya terhadap Islam yang menurutnya melarang untuk boleh memahami kitab isi dari kitab Al-Qur'an. Berikut surat Kartini pada 15 Agustus 1902:

“Dan waktu itu aku tidak mau lagi melakukan hal-hal yang tidak tahu apa perlu dan manfaatnya. Aku tidak mau lagi membaca Alquran, belajar menghafal perumpamaan-perumpamaan dengan bahasa asing yang tidak aku mengerti artinya. Jangan-jangan, guruku pun tidak mengerti artinya. Katakanlah kepada aku apa artinya, nanti aku akan mempelajari apa saja. Aku berdosa. Kitab ini teralu suci, sehingga kami tidak boleh mengerti apa artinya". (Sutrisno, 1985, p. 241)

Namun selang beberapa bulan kemudian, isi surat Kartini kepada Ny. Abendanon menjadi berbeda. Kartini seakan menemukan jawaban atas pencariannya selama ini tentang agama Islam. Menurut Kartini, bukan salah agamanya, namun karena perbuatan pemeluk agama yang menjadikan hal yang buruk terjadi. Hal itu dilihat pada kutipan surat Kartini kepada R.M. Abendanon pada 12 Desember 1902.

"Inilah yang menyebabkan kami demikian lama membelakangi agama secara sungguh-sungguh, karena kami banyak sekali melihat peristiwa yang menunjukkan ketiadaan kasih sayang yang dilakukan orang dengan berkedok agama. Lambat laun barulah kami tahu, bukan agama yang tiada kasih sayang, melainkan manusia juga yang membuat buruk segala sesuatu yang semula bagus dan suci itu"

R.M. Abendanon adalah seorang feminis liberal yang beragama Kristen sehingga secara tidak langsung pemikiran dan agamanya mempengaruhi pemikiran Kartini tentang feminisme dan agama. Menurut Sumartana (2013, p. 53), tampaknya Kartini terdesak untuk mengulangi pertanyaan tersebut. Mungkin Ny. Abendanon berpandangan bahwa hanya agama Kristenlah yang bisa membawa manusia kepada kebenaran sejati itu. Kartini ternyata menolak pendapat tersebut. Kartini konsekuen dengan pandangan bahwa semua agama adalah berkah Tuhan untuk semua orang, tanpa melihat ras, bangsa, warna kulit, dan latar belakang kebudayaan mereka.

\section{Stella Zehandelaar}

Perkenalan Stella dengan Kartini diawali dengan sebuah iklan yang dipasang oleh Kartini pada sebuah majalah Belanda bernama De Hollandsche Lelie dalam edisi 15 
Maret 1899. Stella adalah seorang wanita Yahudi di Amsterdam dan seorang pejuang feminis yang radikal dan lima tahun lebih tua dari Kartini (Bouman, 1954, pp. 28-29). Stella seorang anggota aktif dari Sociaal Democratische Arbeiderspartij (SDAP), sebuah partai pengusung sosial-demokrat di Belanda yang memperjuangkan sosialisme dan humanisme termasuk ide-ide tentang kesetaraan gender. Dalam suratnya kepada Stella Zehandelaar bertanggal 6 November 1899, Kartini menulis;

\begin{abstract}
“Mengenai agamaku, Islam, aku harus menceritakan apa? Islam melarang umatnya mendiskusikan ajaran agamanya dengan umat lain. Lagi pula, aku beragama Islam karena nenek moyangku Islam. Bagaimana aku dapat mencintai agamaku, jika aku tidak mengerti dan tidak boleh memahaminya? Alquran terlalu suci; tidak boleh diterjemahkan ke dalam bahasa apa pun, agar bisa dipahami setiap Muslim. Di sini tidak ada orang yang mengerti Bahasa Arab. Di sini, orang belajar Alquran tapi tidak memahami apa yang dibaca. Aku pikir, adalah gila orang diajar membaca tapi tidak diajar makna yang dibaca. Itu sama halnya engkau menyuruh aku menghafal Bahasa Inggris, tapi tidak memberi artinya. Aku pikir, tidak jadi orang soleh pun tidak apa-apa asalkan jadi orang baik hati. Bukankah begitu Stella?". (Kartini, 2011, p. 26)
\end{abstract}

Karena itu, melalui surat-surat Kartini pada sekitar 1899, terlihat bagaimana pemikiran Kartini yang terpengaruhi oleh semangat feminisme radikal Stella sehingga sering membahas tentang perjodohan dalam adat Jawa yang dikecam oleh Kartini, dan itu dilindungi oleh agamanya, Islam. Namun itu menjadi sedikit berbeda setelah Kartini berkorespondensi dengan Ny. van Kol dan Ny. Abendanon tentang pemikiran agama Kartini. Kartini tidak begitu memperlihatkan keradikalannya dalam mempersoalkan agama dan adat Jawa. Kartini mulai tersentuh pengaruh liberalisnya Ny. Abendanon dan humanisnya Ny. van Kol yang keduanya beragama Kristen.

\title{
Ayah Kartini
}

Ayah Kartini adalah orang nomor satu yang berhak mengatur hidup Kartini, dan Kartini sangat patuh terhadapnya. Kepatuhan itu terlihat dari kesediaan Kartini menerima perjodohan dengan Bupati Rembang oleh sang ayah. Perjodohan itu ditanggapi oleh Stella dengan perasaan sangat kecewa. Penerimaan terhadap perjodohan itu dianggap dapat menghentikan cita-cita Kartini. Terlihat dalam kutipan berita kematian yang ditulis oleh Stella untuk mengenang Kartini bahwa Kartini dengan terpaksa menikah dengan Bupati Rembang melalui perjodohan dan setahun kemudian Kartini harus membayar kelahiran anak laki-lakinya dengan nyawanya (Yulianto, 2004, p. 206). Namun demikian, Stella juga memahami bahwa peran Ayah Kartini sangat besar dalam menentukan hidup Kartini. Hal itu dapat dilihat dalam surat Stella kepada Ny. Nellie van Kol pada 26 September 1904.

“Aku sedih sekali dengan keputusan Kartini (untuk menikah) sehingga rasanya tidak mungkin untuk menulis tentang hal itu. Ini membuatku terlalu sedih untuk menceritakannya. (Dengan menikah) Kartini telah berbohong mati-matian. 
Seseorang seperti aku yang telah mengembara bersama dengan pikiranpikirannya dengan begitu mesra selama lima tahun terakhir ini, aku sangat tahu kalau dia telah mengingkari salah satu dari cita-cita besarnya. Seharusnya orang terpilih seperti dia tidak boleh mengorbankan cita-cita hidupnya hanya demi satu orang". (Bouman, 1954, p. 63)

Terlihat dari kalimat 'satu orang' di atas bahwa Stella sadar kunci hidup Kartini ada di tangan Ayah Kartini. Dapat dilihat pula begitu besar peran Ayah Kartini kepada pemahaman agama Kartini yang mengajarkan Kartini tentang sopan santun ala priyayi Jawa, dan pendidikan Islam dari keluarga besar Ayah dan Ibu Kartini.

\title{
Kiai Sholeh Darat
}

Kiai Sholeh Darat, seorang ulama dari Semarang yang produktif menulis sejumlah kitab (Muchoyyar, 2002, p. 1-17). Najmuddin (2013) menyatakan Fadhila Sholeh, cucu dari Kiai Sholeh Darat menuturkan, bahwa takdir mempertemukan Kartini dengan Kiai Sholeh Darat dalam sebuah pengajian di pendopo rumah Bupati Demak, Pangeran Ario Hadiningrat yang juga merupakan paman Kartini. Pada saat itu, sang kiai menerangkan tafsir dari surat Al Fatihah. Kartini yang ikut menyimak, tidak kuasa untuk menyampaikan sesuatu kepada Kiai Sholeh Darat di akhir acara, seperti pada percakapan berikut ini.

\begin{abstract}
"Kyai, perkenankan saya bertanya bagaimana hukumnya apabila seorang berilmu menyembunyikan ilmunya?" Kartini membuka dialog. Kyai Sholeh tertegun. "Mengapa Raden Ajeng bertanya demikian?" Kyai Sholeh balik bertanya. "Kyai, selama hidupku baru kali ini aku berkesempatan memahami makna surat Al Fatihah, surat pertama dan induk Al-Quran. Isinya begitu indah, menggetarkan sanubariku." Ujar Kartini. "Bukan buatan rasa syukur hati ini kepada Allah. Namun, aku heran mengapa selama ini para ulama melarang keras penerjemahan dan penafsiran Al-Quran ke dalam Bahasa Jawa. Bukankah Al-Quran adalah bimbingan hidup bahagia dan sejahtera bagi manusia?". (Najmuddin, 2013)
\end{abstract}

Kartini telah menggugah kesadaran Kiai Sholeh untuk melakukan pekerjaan besar, yaitu menerjemahkan Alquran ke dalam Bahasa Jawa. Terjemahan Al-Qur'an dari surat Alfatihah hingga surat Ibrahim dalam bahasa Jawa-Arab (pegon) dikenal dengan kitab Faidhur Rohman kemudian menjadi hadiah pernikahan Kartini, yang konon menjadi tafsir Qur'an pertama di Nusantara dalam bahasa Jawa dengan aksara Arab (Hamid, 2013; Tim Sarkub, 2012). Kartini mempelajarinya secara serius, hampir di setiap waktu luangnya. Namun sayangnya, penerjemahan Kitab Faidhur-Rohman ini tidak selesai karena Kiai Sholeh Darat telah wafat.

Kiai Sholeh Darat membawa Kartini ke perjalanan transformasi spiritual. Pandangan Kartini tentang Barat (Eropa) mulai berubah. Perhatikan surat Kartini bertanggal 27 Oktober 1902 kepada Ny Abendanon. 


\begin{abstract}
"Sudah lewat masanya, semula kami mengira masyarakat Eropa itu benarbenar yang terbaik, tiada tara. Maafkan kami. Apakah ibu menganggap masyarakat Eropa itu sempurna? Dapatkah ibu menyangkal bahwa di balik yang indah dalam masyarakat ibu terdapat banyak hal yang sama sekali tidak patut disebut peradaban. Tidak sekali-kali kami hendak menjadikan muridmurid kami sebagai orang setengah Eropa, atau orang Jawa kebarat-baratan."
\end{abstract}

Dalam suratnya kepada Ny. van Kol pada 21 Juli 1902, Kartini juga menyatakan bahwa ia bertekad dan berupaya untuk memperbaiki citra Islam yang pada saat itu kerap menjadi perdebatan. Kemudian Surat Kartini kepada Ny. Abendanon pada 1 Agustus 1903 menyatakan bahwa dirinya lebih memilih menggunakan gelar Hamba Allah.

\title{
Rekonstruksi Pemikiran Keagamaan sebagai Upaya Penguatan Integrasi Bangsa Eropa dan Islam bagi Kartini
}

Berbicara tentang Eropa, pada mulanya Kartini sangat membanggakan Eropa, terlebih Belanda (Surat Kartini kepada Ny. Abendanon-Mandri tertanggal 27 Oktober 1902, dalam Sutrisno, 1992, p. 115). Bangsa Eropa dianggap sebagai bangsa yang beradab dan membawa banyak kemajuan. Oleh sebab itu, Kartini sangat berharap kelak dapat mengunjungi dan belajar di Belanda sebagai bekal untuk memajukan pendidikan kaum Bumiputera, terlebih perempuan Jawa.

Dibandingkan bergaul dengan masyarakat bumiputera, Kartini lebih banyak bergaul dengan teman yang berasal dari Eropa, baik secara langsung maupun lewat korespondensi. Namun seiring dengan perkembangan ilmu pengetahuan, dan wawasan yang dimiliki Kartini, akhirnya ia dapat mengetahui dan mengerti bahwa orang Belanda tidak seutuhnya baik. Zending yang dibingkai dengan kegiatan sosial, sekalipun terlihat sangat humanis, dan pada awalnya mendapatkan pujian dari Kartini, akhirnya justru dikecam dengan keras. Kaartini memperingatkan kepada Pemerintah Hindia Belanda agar tidak menggalakkan zending yang bertujuan untuk "menashranikan" orang yang sudah beragama. "Usahakan zending itu, tetapi tidak dengan menashranikan orang!" (Surat Kartini kepada Tuan E.C. Abendanon, 31 Januari 1903).

Islam adalah agama Kartini. Islam yang berkembang di zaman Kartini tidak semulus ketika Islam dijadikan agama resmi kerajaan, yang kemudian memengaruhi sistemnya menjadi Islami dari yang asal-mulanya adalah Hindu-Buddha. Seharusnya, jika ulama-ulama di zaman dahulu dalam mengajarkan dan menyebarkan agama Islam di pulau Jawa tidak mendapatkan gangguan dari Belanda yang dapat menguasai kerajaan-kerajaan Islam, maka perkembangan Islam, khususnya di Jawa akan menjadi dinamis (Ulum, 2015, p. 164). Anak-anak muslim akan dikenalkan dengan baik tentang Islam, seperti yang dapat dijumpai di pesantren dan tempat kajian Islam lainnya.

Ajaran Islam yang ada di lingkungan Kartini sangat terbatas dan dibatasi gerakgeriknya oleh Belanda karena hal ini bisa membahayakan kekuasaan mereka. Oleh 
sebab itu, sangat wajar jika Kartini tidak mengerti tentang Islam kecuali hanya kulitnya saja tanpa mengerti maksud "mengapa" atau "apa" amalan yang ada dalam Islam. Selain itu, keluarga Kartini juga lebih kuat dalam penerapan ajaran kejawen, jika dibandingkan dengan ajaran Islam.

Kartini yang merupakan perempuan priyayi Jawa tentu lebih mudah mengakses ilmu Eropa jika dibandingkan dengan ilmu agama, dalam hal ini Islam. Jika ingin belajar ilmu agama, maka Kartini harus berjalan jauh keluar kadipaten. Akan tetapi, Kartini tidak diizinkan keluar dari kadipaten, sekadar untuk belajar. Kenyataan itu kemudian membuat Kartini tumbuh dengan diiringi rasa kecewa yang mendalam, sebab Kartini tidak dapat memahami sepenuhnya ajaran Islam, terlebih makna yang terkandung dalam Al-Qur'an.

Pada mulanya, Kartini menganggap kawan-kawannya dari Eropa sebagai satusatunya kaum yang mendukung segala pemikirannya bahwa perempuan harus mendapatkan pendidikan yang layak. Selain itu, Kartini juga sangat membenci poligami. Pengetahuan Kartini yang terbatas tentang Islam dan berdasar pengamatan yang kritis tentang poligami, membuat Kartini berfikir bahwa Islam melindungi poligami, Ia bahkan mengeluarkan pernyataan mengenai poligami yang menurutnya menindas perempuan Jawa.

Namun setelah pertemuannya dengan Kiai Sholeh Darat, Kartini mengalami transformasi spiritual khususnya tentang pendidikan dan kedudukan perempuan dalam Islam. Ajaran Islam dan pendidikan wanita itu tidak dapat dipisahkan. Islam sangat memuliakan kaum wanita. Surga Allah tidak akan didapat oleh seseorang jika tidak mendapatkan restu dari seorang Ibu. Nabi Muhammad saw memuliakan seorang ibu tiga tingkat lebih tinggi daripada ayah. Di dalam Al-Qur'an ada surat AnNisa' yang bermakna perempuan; namun tidak dijumpai surat Ar-Rijaal yang bermakna laki-laki. Hal ini menunjukkan bagaimana Islam mengangkat derajat wanita dari zaman jahiliah menuju peradaban yang lebih mulia. Itulah pemahaman yang didapat Kartini setelah mendalami agamanya sendiri. Kartini menjadi lebih dewasa dalam menjalani statusnya sebagai seorang istri bupati yang masih berkesempatan mendidik anak didik di sekolah bentukannya; meskipun tidak mampu mendidik anak kandungnya sendiri karena telah wafat empat hari setelah melahirkan putra pertamanya.

Cerita hati Kartini melalui surat ternyata bukan hanya tentang kisah perjuangannya memperjuangkan emansipasi wanita dalam menuntut haknya. Kartini juga menuliskan bentuk keprihatinannya tentang agama, ajaran, dan implementasinya. Latar belakang sebagai perempuan priyayi Jawa, membuat pemahaman Kartini tentang agama Islam tidak terlalu kuat layaknya kaum laki-laki dari golongan santri karena laki-laki memang diberikan keluasan untuk mendalami agama Islam, sedangkan perempuan sangat terbatas. Meskipun kakek dari garis ibu adalah seorang kiai, hal itu tidak lantas membuat Kartini memahami isi Al-Quran. Adat Jawa dan ajaran Kejawen tampaknya juga memberikan pengaruh pada kehidupan spiritualnya. Pemahaman Kartini tentang agama adalah bentuk pengalaman dan pergumulan batin akan apa yang sedang terjadi pada masanya. 
Setelah bertemu dengan Kiai Sholeh Darat, Kartini mengetahui penyebab pergulatan batin dan kekecewaannya atas keterbatasan masyarakat Bumiputra mendalami agama Islam. Penyebabnya tidak lain adalah pelarangan pemerintah kolonial Belanda untuk menerjemahkan Al-Qur'an pada saat itu. Tujuan Kolonial Belanda tidak memperbolehkan ajaran agama diajarkan oleh para kiai dan ulama saat itu, sebagai upaya menahan laju perkembangan agama Islam (Abidin, 2015, p. 13). Untuk menyelesaikan masalah tersebut, Kartini mengungkapkan gagasannya agar misionaris Kristen di Jawa tidak dilanjutkan pemerintah Kolonial Belanda untuk mencegah terjadinya perang antaragama.

Menurut Kartini pada dasarnya agama merupakan sesuatu yang bersifat rohani dan suci dan tidak bisa dipaksakan. Kartini juga berharap agar program sekolahsekolah bentukan pemerintah kolonial Belanda tidak diembel-embeli dengan agama tertentu (Kristen). Pendidikan (agama maupun umum) juga harus dibuka seluasluasnya oleh pemerintah kolonial Belanda, sebagai upaya pemahaman agama yang dimiliki masyarakat Bumiputera itu menyeluruh, tidak dogma-dogma yang tanpa makna.

Kartini lahir dan meninggal sebagai seorang muslimah. Sudah sejak kecil Kartini biasa mendengar ajaran bahwa Tuhan itu Esa. Kartini bukan penganut politeisme. Kartini mengaku sebagai seorang monoteisme: “Tiada Tuhan kecuali Allah! Kata kami umat Islam, dan bersama-sama kami semua beriman bahwa "Allah itu Tuhan, Pencipta alam semesta".

Menurut Kartini, di dalam hidup dan seluruh sejarah hanya ada satu Tuhan. Tuhan yang Esa, yang satu-satunya itu oleh penganut agama lain disebut Tuhan, tetapi umat Islam memanggil-Nya dengan nama Allah. Kartini menulis surat kepada Dr. N. Adriani, seorang misionaris yang bertugas di wilayah Poso, Sulawesi Tengah. Dr. N. Adriani dikirim oleh Lembaga Alkitab di Belanda. Namun demikian, ia enggan menyebut dirinya sebagai zendeling (misionaris Kristen).

Kartini percaya bahwa hanya ada satu Tuhan. Satu Tuhan untuk sekalian makhluk. Tuhan menciptakan manusia bersifat khilaf, dan agama diciptakan agar manusia dapat dijauhkan dari segala perbuatan dosa. Dengan bahasa yang positif, maka agama diberikan Tuhan kepada manusia sebagai berkah.

Monoteisme Kartini benar-benar membuka pikiran Kartini akan suatu pandangan yang mencakup segala sesuatu secara universal. Seluruh universum diciptakan oleh Allah yang Esa. Manusia di seluruh dunia dipersatukan dan dirangkum bersama-sama sebagai saudara, dan agama diberikan oleh Allah sebagai berkah kepada semua manusia, dalam segenap lapisan, bangsa, warna kulit, lelakiperempuan, pangkat-tingkat, serta kepercayaan mereka. Universalisme semacam ini memang secara langsung sangat mendukung pemikiran Kartini, khususnya yang menyangkut kerja sama antara Bangsa Barat dan Bangsa Timur. Ide "asosiasi" yang berdasar pada kebutuhan mempererat pertalian antara Kebudayaan Barat dan Timur juga memperoleh dukungan secara religius dalam bentuk universalisme semacam ini.

Saling menolong dan membantu serta saling mengasihi, itulah dasar agama. Agama yang diberikan Allah sebagai berkah bagi manusia. Dengan demikian, kerja 
sama antarbangsa sangat dimungkinkan, meskipun bangsa-bangsa itu mempunyai budaya dan agama yang berbeda-beda. Dalam arti khusus, Kartini menyebut hubungan dan kerja sama antara Hindia dan Belanda, Eropa dan Hindia Belanda. Menurut Kartini, kedua bangsa dan benua yang berbeda budaya serta agama itu harus saling mendekatkan diri.

Universalisme dalam bidang agama bukan suatu keyakinan yang berdiri sendiri, dan bukan hanya punya arti secara religius, tetapi memberikan implikasi yang lebih luas. Kartini mengutarakan bahwa ibunya (yang dimaksud mungkin Raden Ayu) bertemu dengan Ny. van Kol untuk mengucap rasa terima kasih, bahwa "Ia tidak seagama dengan kita, tetapi tidak mengapa. Tuhannya kita, Tuhan kita semua". Dalam pengakuan semacam ini, maka batas antara Barat dan Timur telah coba dijembatani (Tamba, 2012).

Dukungan J.H. Abendanon terhadap gagasan Kartini secara langsung juga disebabkan karena ia menyetujui pandangan tentang universalisme keagamaan. Ia juga berpendapat bahwa dalam kehidupan beragama, sudah semestinya manusia saling mendekat satu sama lain. Mereka mengingatkan agar semua saling bekerja sama demi kepentingan kemanusiaan.

Sekalipun Kartini percaya bahwa semua manusia bersaudara, namun ia masih ragu, hingga tersimpan pertanyaan di benaknya, "Betulkah agama itu berkah bagi manusia?" Keraguan ini telah membawanya kepada suatu krisis kepercayaan terhadap agama. Ia bahkan beranggapan bahwa jika tidak ada agama, maka mungkin dunia akan menjadi lebih baik. Tidak akan ada perang yang dijalankan atas nama agama. Kartini melihat agama bukan dari ajaran yang dikandungnya, melainkan terutama fungsinya dalam masyarakat untuk memengaruhi etika atau tingkah laku dan perbuatan para pemeluknya. Ia tidak melihat keperluan untuk mendukung persaingan dan pertentangan antaragama berdasar kelebihan serta keunggulan agama tertentu dibandingkan dengan agama yang lain. Tidak ada agama mengajarkan kejahatan, kecuali agama tersebut telah dimanipulasi dan diselewengkan oleh pemeluknya sendiri. Perhatian Kartini tertuju kepada manusianya, para pemeluk agama itu, dan pada perbuatan para pemeluknya.

Dalam hubungan ini, Kartini memandang bahwa serangan terhadap agama tertentu tidak perlu terjadi. Apabila ada kritik, maka kritik itu harus secara langsung ditujukan kepada si pelaku dan terlepas dengan agama yang dianutnya. Seseorang yang bersikap fanatik, tidak toleran, menghina, serta memandang rendah agama lain, misalnya, itu bukan disebabkan oleh agama yang dianutnya, melainkan karena orang itu bersikap picik, suka menghina, dan tidak mampu bersikap toleran terhadap kepercayaan orang lain.

Berdasar surat-suratnya kepada para sahabat di negeri Belanda, Kartini mengemukakan pandangan dan pemahaman tentang agama, Tuhan dan ajarannya. Kartini menginginkan agar hubungan antarmanusia dan antarbangsa tidak dipecah belah karena perbedaan agama. Manusia justru seharusnya bersatu, bekerja sama untuk melaksanakan tujuan kemanusian. Dalam pandangan Kartini, semua agama adalah baik dan mengajak kepada kebaikan. Semua agama pasti mengajarkan 
kebaikan terhadap umatnya. Kartini prihatin akan perpecahan karena agama. Agama dijadikan alasan pembenaran akan perbuatan manusia, untuk melakukan kekerasan terhadap sesamanya. Agama malah semakin memisahkan manusia yang satu dengan yang lainnya, sangat jauh dari inti dari ajaran agama yang sebenarnya. Kartini melihat peristiwa yang menunjukkan ketiadaan kasih sayang yang dilakukan orang dengan kedok agama.

Kartini menyatakan bahwa bukan agama yang tiada kasih sayang, melainkan manusia yang membuat buruk segala sesuatu yang semula baik dan suci. Hal ini disebabkan oleh pemahaman dan penyimpangan oleh umat manusia. Manusia semakin merusak agama itu sendiri. Orang Buddha, Hindu, Yahudi, Kristen, Islam bahkan orang kafir pun dapat juga hidup dengan kasih sayang yang murni.

Kartini memandang bahwa semua agama itu sama. Tidak ada yang lebih tinggi atau yang lebih rendah. Agama adalah bentuk jalan yang diciptakan Tuhan sebagai jalan yang berbeda-beda namun mengarah pada satu tujuan yang sama, yakni Tuhan itu sendiri. Kartini meyakini bahwa setiap agama pasti mengajarkan kebaikan terhadap sesama, lingkungan, makhluk hidup, dan ketaatan kepada Tuhan. Jika ada agama yang tidak menyerukan itu, Kartini dengan cerdas mengritiknya.

Kartini memandang bahwa jalan yang berbeda itu pada dasarnya sama mengarah pada kebaikan. Kebaikan di sini bukan diartikan menjadikan kebaikan sebagai Tuhan, melainkan Kartini menyakini setiap agama mengajarkan manusia untuk menjadi manusia yang baik. Kebaikan ini juga dijadikan para humanis dan atheis untuk menolak beragama dan ber-Tuhan asal menjadi manusia yang baik. Kartini juga tidak setuju jika manusia terlalu menjunjung tinggi kebaikan dan mengabaikan agama. Kartini berpendapat bahwa manusia bisa menjadi pribadi yang baik karena beragama. Manusia yang beragama pasti memiliki Tuhan, dan manusia yang taat dengan Tuhannya, pasti menjadi manusia yang baik.

Tidak ada alasan untuk saling membenci, saling menghina, saling membunuh, dan saling menistakan karena alasan agama, karena semua agama bermuara pada satu tujuan, yaitu taat pada Tuhan. Kartini menekankan persatuan dan saling bekerja sama memikirkan masalah perbaikan kemanusiaan, bukan terpecah karena masalah perbedaan agama. Apabila ada manusia yang tidak baik, maka menurut Kartini bukan salah agamanya, tetapi manusia itu sendiri karena semua agama itu mengajak untuk melakukan kebaikan.

\section{Simpulan}

Pemikiran Kartini mengenai keagamaan bersifat terbuka dan pluraslistik (apalagi jika dibandingkan pada masa sekarang). Kartini memandang bahwa apa yang ada semuanya diciptakan oleh Tuhan yang tunggal. Manusia dipersatukan dalam bentuk ikatan persaudaraan tanpa melihat lapisan, pangkat, dan warna kulit. Agama dibentuk bukan untuk memisahkan antara umat yang satu dengan umat yang lain. Agama dimaksudkan untuk membentuk tali silaturahmi antara sesama makhluk Tuhan, baik berkulit putih maupun coklat. Agama diciptakan untuk semua manusia, 
tidak memandang pangkat, gender, serta kepercayaan. Hal itu karena semua manusia adalah makhluk ciptaan Tuhan Yang Maha Esa.

Gagasan yang dikemukakan oleh Kartini dalam bentuk keprihatinan dan pandangannya tentang agama lewat surat-surat yang dikirimkan untuk sahabatsahabatnya di Negeri Belanda seratus lima belas tahun yang lalu, tampaknya sangat relevan jika dikaitkan dengan Indonesia pada masa sekarang. Dengan segala keterbatasan pada waktu itu, Kartini sudah berfikir tentang perpecahan dan perbedaan agama. Indonesia pada masa sekarang dengan masa Kartini yang hidup seabad sebelumnya, tentu sangat jauh berbeda dalam segi pembangunan dan modernisasi, namun masalah perpecahan dan perselisihan karena agama tampaknya sudah menjadi masalah klasik yang tetap ada.

Jika Kartini masih hidup, betapa banyak tulisan-tulisannya di media pers untuk memekikkan persatuan yang sering goyah akibat perbedaan agama. Kartini akan menjadi motor penggerak demonstrasi di beberapa tempat tentang segala bentuk kekerasan dan agama. Orasi-orasinya akan menjadi berita utama di media massa, baik nasional maupun internasional. Kartini akan selalu tampil di media telekomunikasi dan media sosial, bukan hanya memperjuangkan emansipasi namun memperjuangkan perdamaian, persatuan, persaudaraan dan cinta kasih.

\section{Referensi}

Abendanon, J.H. dan Allard Elisabeth (1976). Door duisternis tot licht; gedachten over en voor het Javaanse volk van Raden Adjeng Kartini. Amsterdam: GE Nabrink.

Abidin, M. Zainul (2015). Komunikasi Agama R.A. Kartini kepada Nyonya Abendanon-Mandri. Jurnal Disprotek, Vol. 6 (2).

Ali, M. (1970). The spread of Islam in Indonesia. Jogjakarta: NIDA.

Aminah (2015). Pemikiran Kartini terhadap Pendidikan Perempuan Dalam Prespektif Pendidikan Islam. Tadarus: Jurnal Pendidikan Islam, Vol. 4 (1).

Bouman, H. (1954). Meer licht over Kartini. Amsterdam: H.J. Paris.

Farela, Aristo (2017). A short history of Java. Surabaya: Ecosystem Publishing.

Fisher, Rob (1999). Philosophical Approach, in Peter Connolly, Approach to the Study of Religion, London and New York: Cassel.

Freire, P. (2005) Pedagogy of the oppressed. New York: The Continum International Publishing Group Inc.

Herusatoto, B. (1991). Simbolisme dalam budaya Jawa, Yogyakarta: PT. Hanindita Graha Widya.

Hick, J. (1988). God and the universe of faiths: essays in the philosophy of religion. London: Macmillan Press.

Kahin, George McTurnan (2013). Nasionalisme dan revolusi Indonesia. Depok: Komunitas Bambu.

Kartini, R.A. (2004). Habis Gelap Terbitlah Terang. Yogyakarta: LkiS Yogyakarta.

KITLV V-LIPI Perwakilan Koninklijk Instituut Voor Taal-Land-en Volkenkunde dengan Lembaga Lembaga Ilmu Pengetahuan Indonesia (2002). Surat-surat kepada Ny. R.M Abendanon-Mandri dan suaminya. Jakarta: Karya Unipress. 
Koentjaraningrat (1984). Kebudayaan Jawa. Jakarta: Balai Pustaka.

Muchoiyyaroh, Lilis (2014). "Pengaruh Wanita-wanita Eropa terhadap Pemikiran Kartini tentang Peran dan Status Sosial Perempuan di Hindia Belanda". Skripsi. FIS UNESA.

Muchoyyar (2002). “K.H. Muhammad Salih al-Samarani, Studi Tafsir Faid al-Rahman Fi Tarjamah Tafsir alam Malik al-Dayyan". Disertasi. IAIN Sunan Kalijaga.

Nadhifah, I. (2017) “R.A. Kartini dan Pendidikan Pesantren (Studi atas Konstribusi dan Peran R.A. Kartini dalam Pendidikan Perempuan)". Skripsi. Universitas Islam Negeri Walisongo.

Najmuddin, A. "Kala Kartini Berguru Pada Kiai", http://www.nu.or.id/a,publicm,dinamic-s, detail-ids,7-id,43963-lang,id-c,fragment,Kala+Kartini+Berguru+ Pada+Kiai+3+habis+-.phpx, diunduh pada 27 Juni 2019,

Soeroto, Sitisoemandari (1984). Kartini, sebuah biografi. Jakarta: Gunung Agung.

Sudarajat (2017). Kartini: Perjuangan dan Pemikirannya. Mozaik: Jurnal Ilmu-Ilmu Sosial Humaniora, Vol. 2 (1).

Sumartana, Th. (2013). Tuhan dan agama dalam pergulatan batin Kartini. Cetakan I. Yogyakarta: Gading Publishing.

Sutrisno, Sulastin (1985). Surat-surat Kartini, renungan tentang dan untuk bangsanya. Yogyakarta: Djambatan.

Tamba, Eko Sanjaya (2012). Pemikiran Kartini Tentang Pluralisme. Online. https://www.kompasiana.com/eko_e/551004b6a333117732ba8155/pemikirankartini-tentang-pluralisme, diakses 16 Oktober 2018.

Tim Sarkub (2012). RA Kartini dan Kyai Sholeh Darat, sejarah bangsa yang digelapkan orientalis Belanda. Online, http://www.sarkub.com/2012/ra-kartini-dan-kyaisholeh-darat-sejarah-bangsa-yang-digelapkan-orientalis-belanda/, diakses 27 Juni 2019.

Toer, Pramoedya A. (2003). Panggil aku Kartini saja. Jakarta: Lintara Dipantara.

Ulum, Amirul (2015). Kartini Nyantri. Yogyakarta: Pustaka Ulum.

Yulianto, Vissia Ita (2004). Aku mau: feminisme dan nasionalisme (surat-surat Kartini kepada Stella Zeehandelaar 1899-1903). Jakarta: Kompas. 